\title{
Case note: rights versus remuneration - the English NHS and abortion services for women from Northern Ireland
}

\author{
SYLVIA DE MARS
}

Newcastle Law School

\begin{abstract}
$\mathrm{T}$ The May 2014 England and Wales High Court decision in $\mathrm{R}$ (on the Application of $A$ and Another) $v$ Secretary of State for Health ${ }^{1}$ in many ways is not a surprising one, though it is likely to have disappointed pro-choice onlookers who are interested in the human rights focus of its main question: are Northern Ireland's residents entitled to obtain abortions with the English NHS free of charge, given that they cannot obtain abortions in Northern Ireland?
\end{abstract}

It is easy to ignore, however, that the question of access to NHS services is primarily one of public law. This judgment is not one that addresses whether or not women resident in Northern Ireland can have abortions in England; it is only one that decides if the English NHS is obliged to pay for abortions obtained by those resident outside of England.

The High Court decided this case by applying public law as it currently stands in England and, though the judgment does not state this explicitly, one would assume that it has done so not least of all because the issue of who can access the English NHS for free has been an increasingly politically sensitive one in recent years. ${ }^{2}$ What few restrictions exist in English law to entitlement to free access to the NHS, the High Court here has upheld by emphasising that healthcare is a devolved matter:

Health Policy within Northern Ireland . . . is thus within the legislative competence of the Northern Ireland Assembly. It is accordingly . . . for the relevant authorities in Northern Ireland to decide to what extent abortion services ... should be provided by the health service in Northern Ireland . . . 3

King J thus stresses that there is no such thing as an NHS that is available to all $U K$ nationals. Northern Ireland and England operate their own health services, which provide their own levels of coverage - both in terms of services provided and persons entitled to access those services.

Provisions on entitlement to treatment by the NHS in England are set out in the NHS Act 2006. Under the NHS Act 2006, anyone who is 'ordinarily resident' in Great Britain is entitled

$1 \quad R$ (on the Application of $A$ and Another) $v$ Secretary of State for Health [2014] EWHC 1364 (Admin), [2014] WL 1220042.

2 See, inter alia, Department of Health, 'Sustaining Services, Ensuring Fairness: A Consultation on Migrant Access and their Financial Contribution to NHS provision in England' (July 2013) <www.gov.uk/dh> accessed 2 July 2014.

$3 \mathrm{R}$ (on the Application of $A$ and Another) (n 1) [19]. 
to use the NHS for free: s 1(3) states that 'free' service is obligatory for all those entitled to use it, unless otherwise noted. An exception is contained in s 175, which entitles the English authorities to introduce additional legislation to recover charges from 'overseas visitors'.

The NHS Act 2006 does not define 'ordinary residence'. In order to make the concept workable in practice, Department of Health guidance ${ }^{4}$ on charging overseas visitors directs NHS employees to apply $\mathrm{R} v$ Barnet LBC ex parte $S h a b^{5}$ when deciding if a visitor is to be charged. In Shah, Lord Scarman ruled that anyone adopting an 'abode' voluntarily and for settled purposes 'as part of the regular order of his life', regardless of how long, would pass an 'ordinary residence' test unless said person's stay in the UK was unlawful. ${ }^{6}$ This ruling was made in the context of the Education Acts, but - as the Department of Health guidance states - 'is generally recognized to have a wider application'? ${ }^{7}$

Key here is where the NHS Act 2006 demands the residence to be. Unlike under the Education Acts, where 'ordinary residence' was demanded in the UK, the NHS Act 2006 demands 'ordinary residence' in Great Britain. It thus explicitly excludes Northern Ireland. The reasoning behind an 'ordinary residence' requirement in order to access social services (including the NHS) is that visitors to the UK should not be entitled to access what are 'free at the point of use' services at the expense of the UK taxpayer. However, as noted, the exception is - in most areas of law - to those not resident in the UK. This was raised by one of the claimant's mothers in $A$ and Another, who said:

Having now had the opportunity of taking legal advice in England, I understand that publicly funded bealth care services are intended to be free at the point of use for all UK residents. I feel my daughter has been treated most unfairly, because when she required treatment in another part of the United Kingdom, she did not get it, and was offered no assistance by the state health care system. If my daughter had had some other health condition, which necessitated her travelling to another part of the UK for treatment, I believe that no obstacles would been put in her way and that every effort would have been made to ensure that she was treated in an appropriate NHS facility and had assistance with travel costs [emphasis added]. ${ }^{8}$

As King J points out, this is a misunderstanding of the relevant legislation. King J, however, does not stress that Northern Ireland is singled out as an exception in primary legislation already, instead, he focuses on the fact that abortion is a 'secondary care service', and these are only provided for local residents, by what used to be primary care trusts (PCTs) and what are now clinical commissioning groups (CCGs). ${ }^{9}$ In short, prior to 2013, funding - as directed from Parliament to the Department of Health and then distributed to PCTs - for secondary care services such as abortion services was proportionate to 'local' populations in areas and the English NHS (through PCTs) was entitled to charge for these services unless they were provided in an emergency (as emergency treatment, regardless of where in England it takes place, is always free), or unless the service was provided for what is termed a 'qualifying patient', as in a patient with serious mental illness as per s $130 \mathrm{C}$ of the Mental Health Act $1983 .{ }^{10}$ Consequently, the law directed the English NHS to charge

4 Department of Health, 'Guidance on Implementing the Overseas Visitors Hospital Charging Regulations' (October 2013) <www.dh.gov.uk/publications> accessed 2 July 2014.

$5 \mathrm{R} v$ Barnet LBC ex parte Shah [1983] 2 AC 309, [1983] 2 WLR 16.

6 Ibid 343.

7 Department of Health (n 4) para 3.4.

$8 \mathrm{R}$ (on the Application of $A$ and Another) (n 1) [12].

9 Ibid [13], [33].

10 Ibid [26]-[28]. 
anyone not locally resident for secondary care services, including abortion access, unless a specific exception applied to them.

The law applicable to CCGs is slightly different, as is summarised well in the judgment:

... the CCGs are in a slightly different position than were PCTs vis à vis the provision of services to persons ordinarily resident in Northern Ireland. Some services must be provided based on the presence in the CCG's area; no such duty applies to other services vis à vis persons ordinarily resident in Northern Ireland (and Scotland and Wales). But there is discretion to commission services, including abortion services, for the benefit of all potential patients, including patients ordinarily resident in Northern Ireland. In this way, decision-making as to the appropriate provision of certain services has been devolved from the Secretary of State to the level of CCG. ${ }^{11}$

As King J ultimately finds in $A$ and Another, the current position of the NHS Act 2006 is that CCGs can provide abortion services (for free) to Northern Ireland residents if they wish to, but there remains no obligation to provide these services free of charge. Rather than accept that, as abortion is illegal in Northern Ireland, the English NHS has a duty to provide abortion services to those 'ordinarily resident' in other parts of the UK, his ruling focuses very explicitly on the fact that the Secretary of State's general duty is to the people of England and that the English NHS cannot be held responsible for the fact that the devolved Northern Ireland Executive has not extended the Abortion Act 1967 to Northern Ireland. ${ }^{12}$

From a functional perspective, there is little to fault in this conclusion. Healthcare is not only a devolved matter in the UK, but it has now even within England become a 'local' matter. Financially, the centralised mechanism whereby health services across the UK are funded is only sustainable if block grants reach CCGs (or the prior PCTs) on the basis of how many residents are likely to need services. This stands separate from Northern Ireland's decision to outlaw abortion and, consequently, the semi-predictable stream of women from Northern Ireland seeking abortions in England; as a matter of public law, the English NHS simply holds no responsibility to provide any secondary care that is 'free at the point of use' for anyone not ordinarily resident in their particular catchment area, unless very specific exceptions apply.

Popular as this functional, 'respectful of devolution' reasoning is likely to be with those concerned about the English NHS's budgetary crisis, however, it ultimately hides behind devolution to ignore the fact that a substantial number of women who have UK citizenship cannot benefit from human rights law applicable within the UK as a whole. It is undoubtedly the case that the Abortion Act 1967 - decriminalising abortion in specific circumstances in England, Wales and Scotland - does not apply to Northern Ireland, ${ }^{13}$ but the claimant attempted to argue that denial of free access to the NHS to obtain this abortion violated Article 14 (on non-discrimination) of the European Convention on Human Rights (ECHR), by way of interference with her Article 8 (right to private life) right:

The claimant would say that she is treated differently from all other citizens of the United Kingdom as regards access to 'state funded abortions' because unlike citizens ordinarily resident in England, Scotland or Wales, she has no option of returning to her place of 'usual residence' in order to access a state funded abortion ...14

$11 \mathrm{R}$ (on the Application of $A$ and Another) (n 1) [33].

12 Ibid [52]-[54].

13 Abortion Act 1967, s 7(3).

$14 \mathrm{R}$ (on the Application of $A$ \& Another) (n 1) [49(3)]. 
King J was quick to dismiss this argument and he did so in formalistic terms. He ruled that there was no such thing as a right to a 'state funded abortion'; rather, that Articles 8 and 14 read together require residents of Northern Ireland to be able to access abortions in England as any other UK citizen can. This duty, he concluded, the Secretary of State had fulfilled, as the claimant did manage to obtain an abortion in England and her right to do so was not legally impeded. What services the NHS provides for free is, in short, not affected by the ECHR; this is a matter of contracting state policy and not specific to abortion as such. ${ }^{15}$

This appears to be a viable interpretation of existing European Court of Human Rights jurisprudence. Tysiac $v$ Poland, ${ }^{16}$ in which the court indicated that abortion services were covered by Article 8 of the ECHR as 'since whenever a woman is pregnant her private life becomes closely connected with the developing foetus', is nonetheless a limited ruling. While it did confirm that state regulations on abortions - which, in Poland, permitted legal abortions only in limited circumstances - had to be considered in light of the positive obligation of the state to secure the 'physical integrity' of pregnant women, it ultimately concluded that Poland's real failure was administrative. ${ }^{17}$ Polish law precluded any possibility for women who were denied legal abortions to have such a decision reviewed, nor could they assert their right to privacy in this matter as a civil tort and, consequently, Polish law contravened Article 8 of the ECHR. ${ }^{18}$ In no way does the European Court suggest, however, that Poland had an obligation to provide abortions to the claimant, let alone provide state-funded abortions; in fact, in later cases, the European Court has stressed that 'the Convention [does] not guarantee as such a right to free medical care and that the state's margin of appreciation when it [comes] to the assessment of priorities in the context of limited public resources [is] a wide one'. 19

However, such an interpretation ignores that all healthcare services in all parts of the UK are provided 'for free' for those eligible to use them, meaning that the right to access such a service outside of the NHS is at best a half-right. No UK nationals outside of Northern Ireland would ever need to make use of their right to privately access abortion services, but that point is sidestepped by the High Court. Similarly ignored is that not all Northern Irish residents would be able to afford a private abortion, which flies in the face of the philosophy underpinning the NHS: it is there to provide treatment on the basis of need, regardless of ability to pay for it.

Additionally, and obiter, King J suggests that there is no discrimination in this case at all, in the sense that the residence requirement for secondary care services stems from the objective, reasonable justification of the 'division of responsibility for health services within the four jurisdictions of the United Kingdom'. ${ }^{20}$ He concludes by saying that devolution would perhaps not function as a justification if the claimant had contested the Northern Ireland law on abortion under the ECHR - but this was not what the claimant did.

One way to view the final point is as a nudge for the claimant to challenge the Northern Ireland law as non-compliant with her Article 8 rights; it reads almost as an expression of regret, whereby King J indicates he cannot simply ignore the public law in order to rule on the human rights issue before him. However, that will be of little consolation for those interested in seeing women's rights protected in the UK as a matter of national law, rather

$15 \mathrm{R}$ (on the Application of $A$ and Another) (n 1) [65]-[66].

16 Tysiac v Poland (5410/03) [2007] 1 FCR 666, (2007) 45 EHRR 42.

17 Ibid [109].

18 Ibid [126]-[127].

19 Wiater $v$ Poland (42290/08) (2012) 55 EHRR SE22 [36].

$20 \mathrm{R}$ (on the Application of $A$ and Another) (n 1) [68]. 
than international law - and, indeed, the High Court appears very unwilling to do as much. Given that the post-2013 restructuring of the NHS has given CCGs the power to grant access to NHS abortions as a matter of discretion, the door to a rights-based argument entitling women from Northern Ireland to obtain state-funded abortions in the rest of the UK appears to have been wide open in this case. While King J observed that the organisational structure of the NHS had changed in this regard as of 2013, he declined to consider this greater freedom of CCGs as anything more than 'optional' and so found that the duty of the Secretary of State for Health to provide a healthcare service for England entitles only those resident in England. A wariness of treading on matters devolved to Northern Ireland pervades the entire judgment and, consequently, it does not go nearly as far as it could.

As it stands, the grounds for further action are clearly there - but, so far, the High Court remains unwilling to rule in a way that clearly informs the Northern Ireland Assembly that its attitude towards abortion is unsustainable in a UK that respects the human rights of its female citizens. The four parts of the UK do not make a whole here and, from the perspective of the rights of UK national women who happen to be resident in Northern Ireland, this is at best regrettable. 
